\author{
Beata Gierczak-Korzeniowska \\ Uniwersytet Rzeszowski \\ Wydział Wychowania Fizycznego \\ Katedra Turystyki i Rekreacji \\ b.gierczak@interia.pl
}

\title{
ZNACZENIE BENCHMARKINGU W DZIAŁALNOŚCI INNOWACYJNEJ PRZEDSIĘBIORSTW TURYSTYCZNYCH NA PRZYKŁADZIE POLSKICH LINII LOTNICZYCH LOT SA*
}

\begin{abstract}
Abstrakt: Celem artykułu jest identyfikacja znaczenia benchmarkingu jako źródła innowacji w działalności przedsiębiorstw turystycznych na przykładzie Polskich Linii Lotniczych LOT. Uszczegółowieniem tego celu jest wskazanie działów firmy, które wykorzystały metodę w poszukiwaniu impulsów rozwojowych do stworzenia nowej lub ulepszenia dotychczasowej oferty. Podmiotem badań była linia lotnicza należąca do Star Alliance oraz pracownicy wybranych działów w liczbie 27 . W ramach badań zastosowano metodę ankietową oraz - tylko w odniesieniu do kierowników wybranych działów - metodę wywiadu jawnego standaryzowanego. Przy analizie danych wykorzystano metody wnioskowania statystycznego, m.in. test niezależności chi-kwadrat. Mimo że wprowadzenie benchmarkingu w struktury przedsiębiorstwa pozwala na szybkie wyrwanie się z kręgu ograniczeń własnej kultury i standardowych zachowań, a zdobywanie wiedzy w trakcie tego procesu daje podstawę do nowych, innowacyjnych pomysłów, to znaczenie metody $w$ działalności innowacyjnej omawianego przedsiębiorstwa nie znajduje odzwierciedlenia w jej praktycznym zastosowaniu. Zauważalny jest przede wszystkim brak wiedzy na temat benchmarkingu, a utożsamianie metody ze zwykłą analizą konkurencji jest skutkiem niepowodzeń i braku kreatywności w jej stosowaniu.
\end{abstract}

Słowa kluczowe: benchmarking, innowacje, przedsiębiorstwo turystyczne, linia lotnicza.

\section{WSTĘP}

Gospodarka turystyczna mimo trwających od roku 1989 procesów dostosowawczych (w ujęciu ilościowym i jakościowym) nadal nie osiagnęła poziomu pełnej dojrzałości. Na tle gospodarek krajów wyżej rozwiniętych dostrzegana jest mniejsza produktywność zasobów pracy oraz niższy poziom innowacyjności przedsiębiorstw turystycznych. Ponadto proste czynniki rozwoju gospodarczego szybko wyczerpują swój potencjał, a kontynuowanie wzrostu wymaga wprowadzania innowacji (PORTER, KETELS, DELGADO 2007). Kluczem do sukcesu jest więc zdolność i szybkość adaptacji oraz innowacji, a także umiejętność zarządzania zmianą (BEDNARCZYK, NAJDA-JANOSZKA 2014).

Innowacyjność przedsiębiorstw turystycznych zależy od wielu czynników wewnętrznych i zewnętrznych. Do grupy czynników wewnętrznych (BRATNICKI, STRUŻYNA, red. 2001, BRACKENBURY 2004) należy zaliczyć m.in.: jego uczestnictwo w transferze wiedzy, jakość zarządzania, gotowość do zmian i zdolność do współpracy z podmiotami z łańcucha wartości, a także dostrzeganie roli innowacji w budowaniu trwałej przewagi konkurencyjnej. Do czynników zewnętrznych kwalifikują się np. zasoby wiedzy, nakłady na badania i rozwój $(B+R)$, poziom współpracy przedsiębiorstw z sektorem nauki. Generalnie można stwierdzić, że aby powstał pomysł na nowy produkt lub proces, musi istnieć nowa wiedza i informacja o oczekiwaniach otoczenia (JANUSZEWSKA, NAWROCKA 2015). Dlatego też w obliczu trwających procesów modernizacyjnych i niwelowania luki konkurencyjnej gospodarki polskiej warto zwrócić uwagę m.in. na metodę zarządzania, jaką jest benchmarking oraz jego rolę w procesie gromadzenia cennej wiedzy i tworzenia innowacji. Gromadzona i rozwijana w organizacji oraz pozyskiwana $\mathrm{z}$ rynku wiedza $\mathrm{w}$ procesie benchmarkingu, ułatwia tworzenie i wdrażanie innowacji. Z kolei powtarzalność i systematyczność analiz benchmarkingowych sprzyja kształtowaniu kultury innowacyjnej. 
Wykorzystanie informacji pochodzących m.in. $\mathrm{z}$ innych przedsiębiorstw oraz konfrontowanie własnej efektywności mierzonej produktywnością, jakością i doświadczeniem $\mathrm{z}$ wynikami tych przedsiębiorstw i organizacji, które można uznać za wzór doskonałości, określa się pojęciem benchmarkingu (KARLÖF, ÖSTBLOM 1995, GABRUSEWICZ, KAMELA-SOWIŃSKA, POETSCHKE 1998, SUSZYŃSKI 2003, LISIECKA 2004). Benchmarking to metoda, która inspiruje do poszukiwania wzorców i pobudza do szybkiego uczenia się od innych oraz tworzenia nowych standardów świadczeń (GARVIN 1993, SIMATUPANG, SRIDHARAN 2003), a także stanowi podstawę do rozwoju organizacji „,uczącej się”.

W pierwszej części opracowania, na podstawie przeglądu literatury, wskazano na znaczenie benchmarkingu w działalności innowacyjnej przedsiębiorstw turystycznych, albowiem już sama decyzja o zastosowaniu metody jest pierwszym i ważnym krokiem w kierunku pozytywnych zmian. W związku z zakresem podmiotowym badań odwołano się do wybranej linii lotniczej i jej działań, mających na celu zwiększenie innowacyjności dóbr oraz usług turystycznych na pokładach samolotów w wyniku zastosowania benchmarkingu. Swój udział w tej części ma również historia pojęcia innowacji, bowiem niejednokrotnie stanowi ona pochodną zastosowania omawianej metody. Kolejna część zawiera metodykę badania oraz wyniki wskazujące na zakres wykorzystania benchmarkingu w podnoszeniu innowacyjności podmiotów gospodarki turystycznej. Rozważania kończą implikacje dla nauki i praktyki gospodarczej.

\section{BENCHMARKING A DZIAŁALNOŚĆ INNOWACYJNA PRZEDSIĘBIORSTWA - UJĘCIE TEORETYCZNE}

Specjalistyczna wiedza i aktualna informacja to jeden z najcenniejszych zasobów współczesnych przedsiębiorstw. To także dwa czynniki będące źródłem innowacji oraz gwarantujące efektywność i poprawność metodologiczną benchmarkingu.

Wszechobecne dążenie do poszerzenia wiedzy o nowych możliwościach rozwoju zjawisk, produktów oraz procesów bardzo często staje się przyczynkiem do zainicjowania działań o charakterze innowacyjnym. Istotę innowacji ${ }^{1}$ wskazuje wysiłek organizacji na rzecz wprowadzenia nowych produktów lub nowych zastosowań. Innowacja to również wdrożenie nowej metody marketingowej lub organizacyjnej ${ }^{2}$ redefiniującej sposób pracy lub relacje firmy $\mathrm{z}$ otoczeniem, w tym kontekście jest ona narzędziem budowania przewagi konkurencyjnej (MARCISZEWSKA 2014). Doskonałym przykładem takich działań, będących jednocześnie przejawem „odważnego nowatorstwa”, jest zaadaptowanie benchmarkingu w struktury przedsiębiorstwa.

Historia benchmarkingu $\mathrm{u}^{3}$ określanego jako innowacyjne adaptacje sięga właściwie początków ludzkości. Przez tysiące lat ludzie podpatrywali dobre pomysły innych, adaptując je do swoich potrzeb i warunków ${ }^{4}$. Początków twórczej adaptacji doszukiwano się już w starożytnym Egipcie oraz Grecji (BOGAN, ENGLISH 2006). Proces benchmarkingu dostarczał ludziom inspiracji $\mathrm{w}$ wielu istotnych momentach, a nierzadko inicjował niezwykłe spostrzeżenia i przełomowe myśli. Ch.E. Bogan i M.J. English określają benchmarking jako proces nieustannego poszukiwania najlepszych praktyk, które po zaadaptowaniu i wdrożeniu w danej organizacji mogą skutkować doskonałą wydajnością. Podkreślają, że w benchmarkingu trzeba położyć nacisk na ciągłość i kompleksowość działań mających na celu zidentyfikowanie najlepszych praktyk operacyjnych, które po wdrożeniu pomogą uzyskać doskonałe wyniki (BOGAN, ENGLISH 2006). Z podobną definicją spotykamy się u A.G. Kamande, według którego benchmarking jest systematycznym i stałym procesem poszukiwania, pomiaru i wdrażania najlepszych rozwiązań. W procesie tym porównuje się najważniejsze procesy gospodarcze $\mathrm{w}$ danej organizacji $\mathrm{z}$ procesami liderów w skali światowej, z zamiarem uzyskania informacji w celu zastosowania lub zaadaptowania najlepszego rozwiązania, co ma pozwolić na poprawę wyników działania danej organizacji w zakresie jej produktów, usług i procesów do poziomu uzyskiwanego przez organizacje wzorcowe (KAMANDE 1997). J. Czekaj dodaje, że benchmarking jest metodą umożliwiającą osiąganie najlepszych wyników przez uczenie się od innych (CZEKAJ 1995). Benchmarking poprzedzony samodiagnozą jest więc jednym z filarów przedsiębiorstwa uczącego się (MICZYŃSKA-KOWALSKA 2005), ponieważ poprzedza fazę wymyślania nowych rozwiązań (BRILMAN 2002, KOWALCZYK 2003).

W przedsiębiorstwie benchmarking najczęściej znajduje zastosowanie w obszarze kształtowania oferty produktowej. Służy on przede wszystkim realizacji imitacyjnych strategii produktu ${ }^{5}$ (HAFFER 1997). Możliwości wykorzystania benchmarkingu w tworzeniu nowatorskich rozwiązań warunkuje w znacznym stopniu zarówno branża, jak i poziom rozwoju przedsiębiorstwa, które stanowi przedmiot analiz porównawczych.

Natomiast pojęcie innowacji cieszy się dużym zainteresowaniem badaczy, przez co w literaturze przedmiotu występuje wiele definicji tego zjawiska. Innovatis jako termin łaciński oznacza odnowę, tworzenie czegoś nowego (WAWRZYNIAK 1999). Innowacja to wprowadzenie do produkcji wyrobów nowych lub doskonalenie dotychczas istniejących, zastosowanie nowej lub udoskonalonej technologii produkcji, nowego sposobu sprzedaży lub zakupu, [...] wprowadza- 
nie zmian w organizacji produkcji (SCHUMPETER 1960, STACHOWICZ-STANUSCH 2001). Niektórzy badacze innowacje analizują również $\mathrm{w}$ ujęciu procesowym, jako działalność organizacji nastawioną na kierowanie i pobudzanie twórczości pracowników, a także w ujęciu rzeczowym, oznaczającą produkt lub usługę będącą wynikiem tej działalności. Inni z kolei określają ją jako każdą myśl, zachowanie lub rzecz, która jest nowa, tzn. jakościowo różna od form istniejących (GRUDZEWSKI, HAJDUK 2000).

Istnieją różne podejścia do klasyfikowania innowacji. W niniejszym opracowaniu przyjęto za A.M. HJALAGER (2010) pięć rodzajów innowacji w turystyce: innowacje produktowe (usługowe), innowacje procesowe, innowacje w zarządzaniu, innowacje marketingowe oraz innowacje instytucjonalne. W kontekście omawianego w niniejszym artykule zagadnienia należy wspomnieć, że ze względu na specyfikę działalności usługowej, w tym turystycznej, w literaturze z zakresu ekonomiki usług i ekonomiki turystyki można doszukać się propozycji klasyfikacji innowacji lepiej oddających odmienność sektora usługowego. Wspomnieć tu wypada o dwóch najczęściej cytowanych klasyfikacjach innowacji usługowych zaproponowanych przez P. von Hertoga. W pierwszej wyróżnia on te, których źródłem są innowacje tworzone przez podmioty sektora produkcyjnego, innowacje mające swe źródło wewnątrz przedsiębiorstwa, innowacje inicjowane przez klientów, innowacje wspomagane przez inne podmioty usługowe oraz innowacje wywołane radykalna zmianą w otoczeniu. Druga klasyfikacja obejmuje: nową koncepcję usługi, nową płaszczyznę współpracy z klientem, nowy system dostarczania usług i nową technologię (za: RAPACZ, JAREMEN 2015).

Część dorobku naukowego poświęcona innowacyjności dotyczy działalności produkcyjnej, podczas gdy sfera usług stosunkowo rzadko stanowi obiekt badawczy w ramach tej problematyki. Nie bez znaczenia jest fakt, iż niemal każda usługa to znaczacco odmienny proces tworzenia wartości, a tym samym niezwykle trudne wypracowanie całościowo spójnej koncepcji procesu innowacji dla działalności usługowej. W przypadku branży turystycznej, która wykazuje wyjątkowo duże wewnętrzne zróżnicowanie działalności usługowej, wiedza prezentowana w opracowaniach naukowych na temat innowacyjności turystycznych podmiotów gospodarczych jest niewystarczająca i w znaczącym stopniu fragmentaryczna (BEDNARCZYK, NAJDA-JANOSZKA 2014). Jest to niekorzystne, gdyż innowacyjność firm turystycznych odgrywa kluczową rolę $\mathrm{w}$ osiąganiu przez nie trwałej przewagi konkurencyjnej. Globalizacja wywiera presję na zwiększenie aktywności innowacyjnej przedsiębiorstw turystycznych warunkującej im nie tylko przetrwanie, ale dalszy wzrost i rozwój (BEDNARCZYK, NAJDA-JANOSZKA 2014).
Istotne wydaje się również to, że innowacja $\mathrm{w}$ firmach turystycznych powinna być tworzona $\mathrm{z}$ myślac o konsumencie, a także przy jego udziale. Sukces odniosą firmy, które będą potrafiły współtworzyć z klientem oczekiwane przez niego wartości, wspólnie kształtować produkt turystyczny (BEDNARCZYK, NAJDA-JANOSZKA 2014).

Do najczęściej wprowadzanych innowacji w turystyce należą produktowe. Innowację produktową definiuje się jako wprowadzenie na rynek produktu, którego cechy technologiczne lub przeznaczenie znacząco różnią się od produktów dotąd wytwarzanych lub którego działanie zostało w znacznym stopniu ulepszone i jednocześnie może on dostarczać konsumentowi obiektywnie nowych lub zwiększonych korzyści (WISZNIEWSKI 1999). W dużej mierze przyczyniają się do decyzji o ich zakupie przez klientów (turystów). Ten rodzaj innowacji może być tworzony w oparciu o nową wiedzę lub technologię, ewentualnie bazować na nowych sposobach użycia dotychczas znanej technologii (OECD 2005). W przedsiębiorstwach turystycznych innowacje są procesem ciągłym i stałym elementem systemu planowania i podejmowania decyzji w firmie. Dla tych firm innowacje sa po prostu dodatkowym czynnikiem produkcji/usługi (BEDNARCZYK, NAJDA-JANOSZKA 2014).

Tak szeroka interpretacja innowacji doskonale wpisuje się w założenia metodologiczne benchmarkingu i pozwala wykorzystać jego możliwości w każdej dziedzinie działalności przedsiębiorstwa. Służy temu m.in. ogromna pojemność rodzajowa metody, jak i nieustanny proces uczenia się oraz zdobywania wiedzy $i$ informacji tak cennych w perspektywie działalności innowacyjnej przedsiębiorstwa, a nierozerwalnie związanych $\mathrm{z}$ metodą benchmarkingu. Benchmarking pozwala ponadto na szybkie wyrwanie się z kręgu ograniczeń własnej kultury i standardowych zachowań. Korzystając z doświadczeń innych - tych najlepszych - przyśpieszamy własny postęp i rozwój, wchodząc na wyższy poziom, a nie tracąc przy tym czasu na stopniowe zmiany i doszkalania.

W liniach lotniczych - przedsiębiorstwach o tak dużym współczynniku działalności innowacyjnej - benchmarking ma charakter utylitarny, skłania do ciągłego śledzenia i analizowania trendów rynkowych, kształtując tym samym umiejętność pozyskiwania i przetwarzania wiedzy, którą rozwinęli inni. Należy jednak pamiętać, że benchmarking nie jest metodą poszukiwania pojedynczych innowacji, mających doraźnie usprawnić przedsiębiorstwo. Jego filozofia zakłada przede wszystkim ciągłe uczenie się od innych - lepszych - a przez to doskonalenie organizacji oraz optymalizowanie działań w oparciu o oryginalne i nowatorskie rozwiązania. 


\section{METODOLOGIA ORAZ WYNIKI BADAŃ}

Na sposoby przeprowadzania badań składają się metody gromadzenia danych, analiza, opracowanie $i$ interpretacja wyników (KOSTERA 2003) z lat 2010-2014.

Podmiotem badań były Polskie Linie Lotnicze LOT należące do sojuszu Star Alliance, natomiast zakres przedmiotowy badań obejmował działania i praktyki benchmarkingowe wybranych działów przedsiębiorstwa oraz ich współpracę $\mathrm{z}$ innymi podmiotami w procesie analizy benchmarkingowej. Wybór - dokonany w sposób celowy - poprzedzony szczegółową analizą struktury i działalności poszczególnych komórek linii lotniczej, doprowadził do wyodrębnienia siedmiu działów, które stanowiły przestrzeń badań.

W tab. 1 wyszczególniono nazwy działów oraz liczbę ich pracowników ${ }^{6}$, których łącznie było 27. Z uwagi jednak na wiarygodność prowadzonych dalej porównań, a także ze względu na podobieństwo pewnych zadań oraz zakresu działań dokonano podziału owych siedmiu działów na trzy podstawowe grupy, według schematu zamieszczonego również $\mathrm{w}$ tab. 1. Do tego podziału będą odnosić się wszystkie badania i zależności, jakie wykorzystano do omówienia tematu niniejszej publikacji.

Powstanie 27-osobowej grupy, stanowiącej wynik celowego doboru próby ${ }^{7}$ do badan, było uwarunkowane kilkoma czynnikami, nie do końca niestety zależnymi od autorki. Po pierwsze - musieli to być pracownicy wymienionych działów, którzy w zabiegach zmierzających do poprawy jakości usług przewozowych, w tym turystycznych, wykorzystują metodę benchmarkingu. Po drugie - niektóre $z$ działów nie były zbyt liczne, co przełożyło się na liczbę kwestionariuszy ankietowych, i wreszcie po trzecie - $z$ zupełnie niezrozumiałych względów w niektórych działach to kierownicy lub dyrektorzy decydowali o liczbie kwestionariuszy, jakie wypełnią pracownicy ich działu. Pozytywny wydźwięk całemu zagadnieniu nadaje fakt, że pozwoliło to na przeprowadzenie bardzo wyczerpujących i szczegółowych badań mających w wielu momentach cechy studiów idiograficznych ${ }^{8}$.
W związku z różnym zakresem obowiązków i odpowiedzialności $\mathrm{w}$ procesie analizy benchmarkingowej, a także na potrzeby niniejszej pracy niezbędny okazał się podział osób poddanych badaniu na dwie grupy: pracowników (59\%) i kierowników (41\%).

W ramach badań wykorzystano metodę ankietową. Aspekt przynależności do danej grupy zawodowej uwzględniono przy tworzeniu kwestionariuszy ankietowych, przygotowując dwa nieco odmienne zestawy pytan. W obu rodzajach ankiet umieszczono pytania dla osób, których zakres obowiązków obejmował współpracę w ramach sojuszu Star Alliance. Natomiast w odniesieniu do omawianego w niniejszej publikacji zagadnienia zapytano m.in. o: powody zastosowania benchmarkingu (wprowadzenie nowych rozwiązań technologicznych), obszary stosowania benchmarkingu, rodzaj stosowanego benchmarkingu, a także o to, czym kierowano się przy wyborze benchmarkpartnera, jakie bariery i problemy pojawiły się przy wdrażaniu benchmarkingu oraz czy w ramach przynależności do aliansu wśród korzyści zastosowania metody znalazły się innowacje produktowe lub inne?

Badania mające charakter jakościowy miały wykazać, w jakim stopniu zastosowanie benchmarkingu przez pracowników linii lotniczej znalazło przełożenie w innowacyjności ofert oraz poprawie jakości usług turystycznych świadczonych na pokładach samolotów. W grupie usług turystycznych znalazły się m.in.: usługa przewozowa, noclegowo-wypoczynkowa, gastronomiczna, kulturalno-rozrywkowa, informacyjna, poradnictwa i pośrednictwa.

Analiza zależności, np. opinii od "działu”, przedstawiona została $\mathrm{w}$ formie zestawienia liczby i struktury procentowej odpowiedzi na wybrane pytania w porównywanych grupach (są to tzw. tabele kontyngencji lub tabele wielodzielcze). Aby ocenić, jak dalece zróżnicowanie odpowiedzi pomiędzy grupami jest odzwierciedleniem pewnej prawidłowości panującej w całej populacji docelowej, a w jakim przypadku może być to tylko kwestia przypadkowych, losowych różnic, zastosowano metody wnioskowania statystycznego (tzw. testy statystyczne ${ }^{9}$ ). W przypadku analizy tabel kontyngencji był to test niezależności chi-kwadrat ${ }^{10}$.

Tab. 1. Rodzaje działów i liczba ich pracowników poddana badaniom

\begin{tabular}{|c|c|c|c|c|c|}
\hline \multicolumn{2}{|l|}{ Dział } & \multicolumn{2}{|c|}{ Liczebność } & \multicolumn{2}{|c|}{ Procent } \\
\hline Aliansów i współpracy międzynarodowej & ucnótprocy mi d-d & 4 & 10 & 15,0 & 37 \\
\hline Sprzedaży & wspotpracy międzynarodowe] & 6 & 10 & 22,0 & 37 \\
\hline Komunikacji marketingowej & \multirow{2}{*}{ marketingu i produktu } & 4 & \multirow{2}{*}{10} & 15,0 & \multirow{2}{*}{37} \\
\hline Produktu i umiejętności obsługi klienta & & 6 & & 22,0 & \\
\hline Personelu pokładowego & \multirow{3}{*}{ personelu lotniczego } & 2 & \multirow{3}{*}{7} & 7,5 & \multirow{3}{*}{26} \\
\hline Doboru i rozwoju personelu & & 3 & & 11,0 & \\
\hline Obsługi naziemnej & & 2 & & 7,5 & \\
\hline
\end{tabular}

Źródło: badania własne. 
W przedsiębiorstwie, jakim jest linia lotnicza znaczenie działań ukierunkowanych na innowacyjność jest nie tylko miarą sukcesu, ale przede wszystkim koniecznością wynikającą ze specyfiki branży. Dodatkowo o rodzaju innowacji decyduje charakter oferowanego produktu, który w lotnictwie może mieć postać rzeczową (tu: techniczną) lub usługową (nietechniczną). Należy jednak mieć na uwadze, że działalność usługowa wymaga odmiennego podejścia, ponieważ innowacja usługowa jest rezultatem procesu zmian wprowadzonych w dziedzinie usług. Cechuje się niematerialnością, zaangażowaniem czynnika ludzkiego, wysokim wpływem czynników zewnętrznych i ludzkich oraz niejednolitością procesu świadczenia usługi (KRUPPER 2001).

Aby określić, jakie znaczenie ma benchmarking w działalności innowacyjnej badanego przedsiębiorstwa warto na początku wspomnieć, że wśród motywów zastosowania metody, jakie wymienili badani pracownicy, wprowadzenie nowych rozwiązań znalazło się na 7. miejscu z liczbą wskazań na poziomie $37 \%$. Niewiele też dało wykorzystanie 13 rodzajów benchmarkingu ${ }^{11}$.

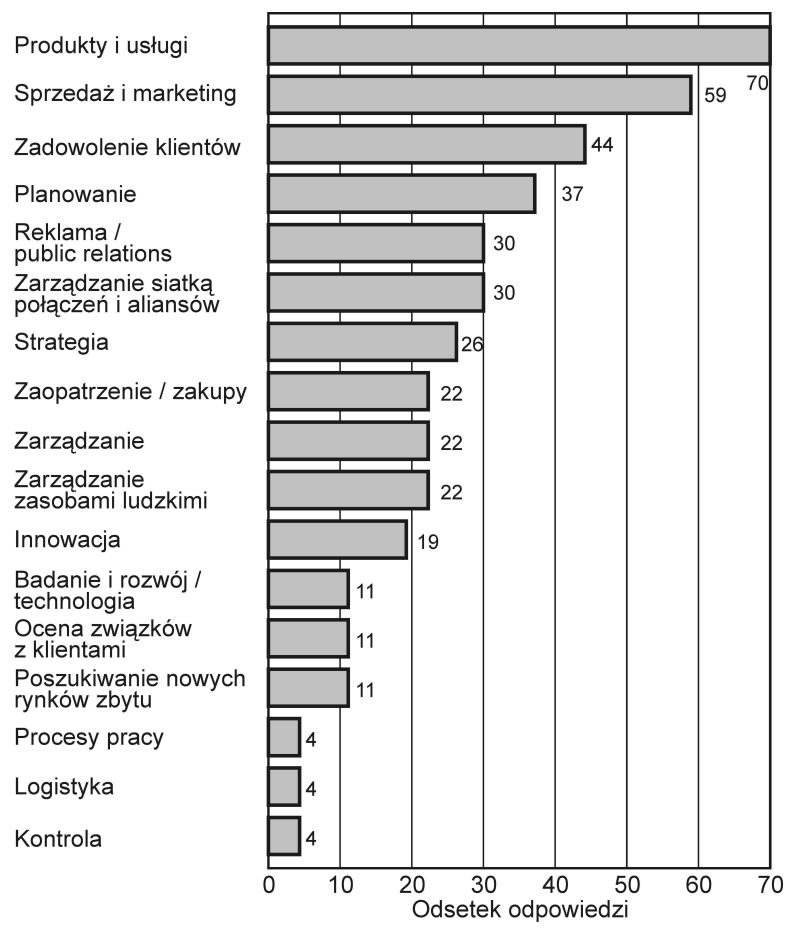

Rys. 1. Obszary stosowania benchmarkingu w badanych działach PLL LOT

a) Odsetek odpowiedzi nie sumuje się do $100 \%$, gdyż była możliwość wskazania dowolnej liczby wariantów odpowiedzi Źródło: badania własne

Na wybór obszarów, w których zastosowano benchmarking w firmie takiej, jaka jest linia lotnicza wpływ miał głównie usługowy charakter przedsiębiorstwa oraz specyfika objętych badaniem działów. Wyniki ba- dań przedstawiono na rys. 1. Wszyscy kierownicy, z którymi przeprowadzono wywiad potwierdzili, że stale starają się wprowadzać $\mathrm{w}$ ofercie coś nowego i podążają za zmianami, jakie wymusza na nich rynek. Stosują w tym celu benchmarking, który jako metoda cieszy się dużą popularnością wśród badanych pracowników, ponieważ wszyscy zdeklarowali jego wykorzystanie $w$ tym celu ${ }^{12}$.

Mimo że coraz częściej pojawiają się nowe zastosowania benchmarkingu $\mathrm{w}$ takich obszarach, jak $\mathrm{np}$ : sposoby projektowania oraz wdrażania nowych rozwiązań (właściwości produktu i wartości postrzegane przez klienta) (RYCHLEWSKI 1998), stosunkowo nisko $\mathrm{w}$ hierarchii znalazły się mocno $\mathrm{z}$ nimi związane zagadnienia dotyczące innowacji $(19 \%)$ oraz badania i rozwój ${ }^{13}$, a także technologia $(11 \%)$, tak istotne dla funkcjonowania transportu lotniczego i pośrednio jakości świadczonych usług. Stan ten jest wynikiem utożsamiania benchmarkingu głównie $\mathrm{z}$ analizą konkurencji i zwykłym porównywaniem, nie zaś z procesem ciągłego dokształcania i zdobywania wiedzy, które są źródłem przełomowych myśli i odkryć, a które stanowią wartość dodaną stosowania metody. Jak wcześniej wspomniano, popularna $\mathrm{w}$ badanych działach PLL LOT, a mylona $z$ benchmarkingiem analiza konkurencji, sprawia, że co najwyżej jest się cały czas $\mathrm{w}$ tym samym miejscu co konkurencja i niekoniecznie ta wzorcowa. Natomiast pożądane jest, aby wynikiem stosowania benchmarkingu była strategia przewodnictwa innowacyjnego.

Analizy obszarów zastosowania benchmarkingu dokonano także uwzględniając podział na działy. $\mathrm{W}$ celu lepszego zobrazowania dysonansu pomiędzy badanymi działami na rys. 2 przedstawiono procentowy udział wskazań tylko dla tych kategorii, które cechuje istotna statystycznie lub zbliżona do statystycznej zależność.

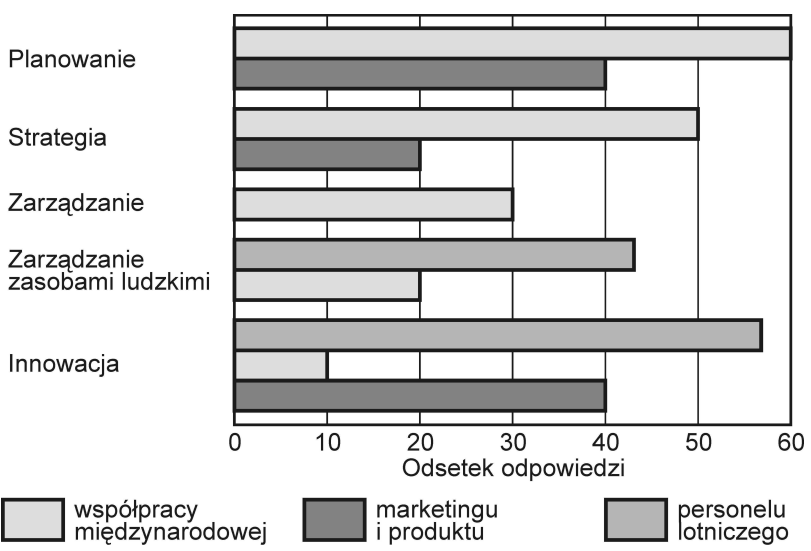

Rys. 2. Obszary stosowania benchmarkingu z uwzględnieniem różnic pomiędzy badanymi działami PLL LOT

a) Odsetek odpowiedzi nie sumuje się do 100\%, gdyż była możliwość wskazania dowolnej liczby wariantów odpowiedzi Źródło: badania własne 
Analiza $\mathrm{z}$ wykorzystaniem testu chi-kwadrat wykazała, że w obszarze innowacji występuje zbliżona do statystycznej zależność ( $p=0,0769$ ). Działanie innowacyjne $(40 \%)$ to domena działu marketingu i produktu, stąd przypuszczenie, że benchmarking w tym zakresie powinien przełożyć się przede wszystkim na korzystniejszy wizerunek linii lotniczej oraz na jakościowe zmiany technologiczne w produkcie. Metodę wykorzystywano m.in. do poszukiwania produktów gastronomicznych, jakie oferowane są na pokładach samolotów, budowy i wyglądu (estetyka) foteli lotniczych oraz sprzętu audio. Z kolei w ramach aliansu benchmarking zastosowano $\mathrm{w}$ odniesieniu m.in. do: standardów produktu pokładowego (chodziło o alkohol), zasad postępowania $\mathrm{z}$ pasażerami niepełnosprawnymi i otyłymi, zapowiedzi pokładowych w więcej niż w dwu językach oraz mobilnego check-in.

Niestety poprzestano tylko na naśladownictwie lub analizie produktowej konkurencji. Nie stwierdzono w badanych działach wprowadzenia w wyniku benchmarkingu produktów nowych na skalę światową tzw. innowacji absolutnych lub przełomowych. Można jedynie mówić o produktach nowych dla tego przedsiębiorstwa, lecz wdrożonych już wcześniej w innych przedsiębiorstwach tzw. innowacjach powielających (STAWASZ 1999). Sami pracownicy przyznawali często, że stan wiedzy na temat benchmarkingu w istotnym stopniu uniemożliwia im pełne wykorzystanie możliwości, jakie metoda ze sobą niesie.

Nie zidentyfikowano zastosowania benchmarkingu w odniesieniu do innowacji procesowych czy organizacyjnych, mimo że zakres zadań badanych działów uzasadniał takie działania. Innowacyjność produktowa, ale i procesowa w ostatnich latach kształtują rzeczywisty obraz konkurencyjności ${ }^{14}$, bowiem na rynku obecnie wygrywają te firmy, które potrafią szybciej niż inne wprowadzić dobry produkt lub usługe i przez to uzyskać oczekiwany zwrot zaangażowanego kapitału. W przedsiębiorstwie, jakim jest linia lotnicza ten aspekt wydaje się być oczywisty, także ze względu na bezpieczeństwo pasażerów oraz rosnącą konkurencję.

Powodów wymienionych zaniechań i nieprawidłowości należy upatrywać w braku merytorycznej wiedzy na temat benchmarkingu wśród pracowników. Samoocena wiedzy na temat metody, jakiej dokonali pracownicy tylko to potwierdza, albowiem 19\%, czyli pięć osób, wystawiło sobie ocenę niedostateczną, ponad połowa pracowników, czyli 15 osób (56\%), dostateczna, a zaledwie siedem osób (26\%), czyli co czwarty ankietowany, oceniło swój poziom wiedzy jako dobry. Taki poziom znajomości benchmarkingu przekłada się na brak poprawności w jego stosowaniu, dlatego częściej wykorzystywanym rodzajem benchmarkingu jest benchmarking nieformalny. Stosuje go 89\%, czyli 24 z 27 pracowników objętych badaniem. Tylko trzech pracowników (11\%) deklaruje częstsze stosowanie benchmarkingu formalnego. Dane te sa niezmiernie istotne dla omawianego $\mathrm{w}$ niniejszej publikacji zagadnienia, gdyż we wdrażaniu innowacji opartych na metodologii benchmarkingu w przedsiębiorstwach usługowych, takich jak np. linie lotnicze (por. GIERCZAK 2014, GIERCZAK-KORZENIOWSKA 2016), istotne jest rozpoznanie determinant innowacyjności. Jedną $z$ nich - główną - stanowią ludzie, pracownicy, których umiejętności, wiedza, zaangażowanie, otwartość na zmiany ułatwiają implementację nowości w organizacji. K. Gadomska postuluje, aby utrwalać działania innowacyjne na każdym etapie procesu kadrowego (GADOMSKA-LILA 2011), po to aby stworzyć zespół i system, w którym poziom kultury innowacyjnej stworzy realną szansę na zdobycie pozycji lidera w branży.

Warto w tym miejscu nadmienić, że natężenie działalności innowacyjnej przedsiębiorstwa determinuje wybór konkretnego rodzaju benchmarkingu. Przykładem takiego zabiegu jest wykorzystanie benchmarkingu funkcjonalnego, który polega na poszukiwaniu możliwości udoskonalenia jakiejś funkcji realizowanej przez przedsiębiorstwo głównie (ale nie wyłącznie) poza własnym sektorem. Przedmiot porównań i analiz $\mathrm{w}$ ramach benchmarkingu funkcjonalnego stosowanego przez pracowników linii lotniczej ${ }^{15}$ przedstawia tab. 3 .

Tab. 3. Rodzaj benchmarkingu lub przedmiot porównania zastosowany $w$ ramach benchmarkingu funkcjonalnego przez pracowników linii lotniczej

\begin{tabular}{|l|c|c|}
\hline $\begin{array}{c}\text { Rodzaj benchmarkingu lub przedmiot } \\
\text { porównania zastosowany w ramach } \\
\text { benchmaringu }\end{array}$ & Liczba & Odsetek a) \\
\hline Projektów & 6 & 40 \\
\hline Rozwiązań logistycznych & 6 & 40 \\
\hline Marketingu i sprzedaży & 6 & 40 \\
\hline Personalny & 5 & 33 \\
\hline Finansowy & 2 & 13 \\
\hline Inwestycji & 1 & 7 \\
\hline Działalności badawczo-rozwojowej & $\mathbf{0}$ & $\mathbf{0}$ \\
\hline Działalności produkcyjnej & 0 & 0 \\
\hline
\end{tabular}

a) Odsetek odpowiedzi nie sumuje się do $100 \%$, gdyż była możliwość wskazania dowolnej liczby wariantów odpowiedzi.

Źródło: badania własne.

Jak wynika $z$ tab. 3, nadal bez zmian pozostaje kwestia działalności badawczo-rozwojowej, która nie znajduje miejsca $\mathrm{w}$ analizach benchmarkingowych prowadzonych przez pracowników linii lotniczej, mimo że rozważania dotyczą jednej z najbardziej innowacyjnych i rozwojowych branż, jaką jest branża lotnicza. Należy dodać, że benchmarking funkcjonalny wymaga największej kreatywności i twórczego myślenia, świadczy też o otwartości menedżerów lub właścicieli na nowatorskie pomysły ${ }^{16}$. Jest bardzo czasochłonny 
- efekty przynosi dopiero po wielu latach. Wiąże się $\mathrm{z}$ trudnościami w znalezieniu właściwego partnera i z samym wdrożeniem tej formy benchmarkingu. Rozwiązania firmy o zupełnie innym charakterze i profilu trzeba bowiem zaadaptować do własnych warunków, potrzeb i możliwości. Jedynym przykładem takiego działania w linii lotniczej, w którym benchmark stanowiło inne przedsiębiorstwo poza linią lotniczą - z jakim spotkała się autorka - było biuro podróży. Porównywanie pewnych funkcji i procesów miało jednak charakter nieformalny.

Warto więc wspomnieć, że doskonałym rozwiązaniem wychodzącym naprzeciw utrudnieniom związanym z pozyskaniem wiedzy zarówno od innych podmiotów, jak i możliwościom wspólnej pracy badawczo-rozwojowej jest realizacja benchmarkingu $\mathrm{w}$ ramach przynależności do aliansów strategicznych. I tu przykładem idealnie realizującym tę koncepcję są alianse integracyjne, które najczęściej są ograniczone do wspólnego prowadzenia prac badawczo-rozwojowych i produkcji. Tworzą je przedsiębiorstwa, w których zamierza się uzyskiwać korzyści w zakresie wytwarzania jakiegoś podzespołu lub realizacji jakiegoś etapu w procesie produkcyjnym. Dlatego na podkreślenie zasługuje fakt, że przy realizacji projektów innowacyjnych i zaawansowanych technologicznie niezmiernie ważne są pozytywne relacje oraz współpraca $\mathrm{z}$ innymi podmiotami, zwłaszcza w sferze prac wymagających zaangażowania ogromnych środków finansowych i specjalistycznej wiedzy.

\section{PODSUMOWANIE}

Swój udział w dążeniu do tworzenia innowacyjnej oferty oraz oryginalnych rozwiązań mają również metody zarządzania, takie jak np. benchmarking. Mimo że w Polsce praktyczne wykorzystanie metody odbiega znacząco od krajów Europy Zachodniej, to znajduje ona coraz szersze zastosowanie w rozwiązywaniu problemów, wyznaczaniu celów, usprawnianiu działań czy wprowadzaniu innowacji17. I nawet, gdy rezultaty podejmowanych działań różnią się od wstępnych założeń i oczekiwań, to sam fakt podjęcia decyzji o zastosowaniu benchmarkingu jest przejawem działań innowacyjnych. Bowiem, jak powiedział J. BANK (1997): „lepiej jest celować w doskonałość i spudłować, niż celować w niedoskonałość i trafić”.

Wyniki badań przeprowadzonych w Polskich Liniach Lotniczych LOT świadczą o bardzo ograniczonym wykorzystaniu benchmarkingu w działalności innowacyjnej przedsiębiorstwa. Mimo możliwości, jakie stwarza przynależność badanej linii lotniczej do jednego z trzech głównych aliansów strategicznych oraz konieczności podyktowanej charakterem branży (m.in. szybki rozwój, wysoka technologia, bezpieczeństwo), zauważalny jest brak inicjatyw w wykorzystaniu metody do działań proinnowacyjnych w badanych działach. Wprowadzane zmiany w ofercie są głównie wynikiem naśladownictwa i mają charakter innowacji powielających lub imitacji innowacji. Trudno więc uznać takie działania za twórcze i kreatywne, nawet wówczas gdy dany produkt (usługa) cieszy się ogromnym zainteresowaniem i uznaniem wśród klientów. Ma to oczywisty związek ze stanem wiedzy na temat metody, jaki zdeklarowali badani pracownicy, a także brakiem świadomości, że u podstaw benchmarkingu leży ciągłe uczenie się i zdobywanie wiedzy. Pozytywny wydźwięk omawianemu zagadnieniu nadaje fakt wdrożenia benchmarkingu w struktury przedsiębiorstwa.

Przedstawione w niniejszej publikacji wyniki i wnioski odnoszą się do konkretnej branży - lotniczej - i ze względu na jej specyfikę powinny w ograniczonym zakresie stanowić przyczynek do generalizowania uzyskanych wyników. Ponadto czas, w jakim autorka prowadziła badania w PLL LOT - zwłaszcza $w$ fazie końcowej - obfitował w wiele mało przychylnych firmie wydarzeń. Linia borykała się z bardzo poważnymi problemami finansowymi, a zamówione wcześniej i sukcesywnie sprowadzane samoloty B787 Dreamliner sprawiały problemy techniczne. Znalazło to swoje przełożenie w pogorszeniu jakości usług i rosnącym niezadowoleniu ze strony pasażerów. Ten już dość mocno nadszarpnięty wizerunek linii pogorszyła krytyka PLL LOT w mediach spowodowana prośbą linii o wsparcie finansowe ze strony państwa. Wszystkie wymienione czynniki oraz wiele innych spowodowały tym samym zmiany $w$ strukturze organizacyjnej firmy, których konsekwencją były m.in. zwolnienia pracownicze, likwidacja niektórych działów lub zmiana ich nazewnictwa, a także wymiana osób na wielu stanowiskach kierowniczych, w tym prezesa Polskich Linii Lotniczych LOT.

\section{PRZYPISY}

\footnotetext{
* Kwalifikacja artykułu - JEL: B21, D04, D21, D83, L23, L91, L93, O31, O32.

1 Zgodnie z Oslo Manual (2005), przez innowację rozumie się wprowadzenie do praktyki $\mathrm{w}$ przedsiębiorstwie nowego lub znacząco ulepszonego rozwiązania $w$ odniesieniu do produktu (towaru lub usługi), procesu, marketingu lub organizacji. Istotą innowacji jest zatem wdrożenie nowości do praktyki, a w przypadku nowego produktu (towaru lub usługi) wdrożenie polega na zaoferowaniu go na rynku. Wdrożenie nowego procesu, nowych metod marketingowych lub nowej organizacji polega na ich zastosowaniu $\mathrm{w}$ bieżącym funkcjonowaniu przedsiębiorstwa.
} 
2 Innowacja organizacyjna to zastosowanie w przedsiębiorstwie nowej metody organizacji jego działalności (MARCISZEWSKA 2014).

${ }^{3}$ Korzenie benchmarkingu tkwią $\mathbf{w}$ geodezji, gdzie benchmark (punkt niwelacyjny) był znakiem wykonanym na skale, ścianie lub budynku. Służył on za punkt odniesienia przy wyznaczaniu lokalizacji lub wysokości obiektu nad poziomem morza w pomiarach topografii terenu i pływów oceanicznych. Benchmark to także punkt odniesienia do dokonywania porównań, coś, co służy jako norma.

4 Przykłady zastosowania benchmarkingu w pracach: CH.E. BOGAN, M.J. ENGLISH (2006), CH.E. BOGAN, D. CALLAHAN (2001), E. CZYŻ-GWIAZDA (2006), M. KOSIŃSKI (2004).

${ }^{5}$ Szacuje się, że imitacja pochłania około $65 \%$ kosztów innowacji produktowej pioniera, a średni czas jej wprowadzenia na rynek to tylko $70 \%$ czasu potrzebnego na rozwój pionierskiej innowacji.

${ }^{6}$ Podana nazwa działu oraz liczba „przebadanych" pracowników odnosi się do okresu, w którym były rozdawane kwestionariusze ankietowe. Jest to kwestia istotna, ponieważ $\mathrm{w}$ trakcie prawie 4-letniej współpracy z linią lotniczą kilkukrotnym zmianom uległy nie tylko nazwy działów i liczba ich pracowników, ale cała struktura przedsiębiorstwa wraz z osobą prezesa.

7 Świadomy, uwzględniający określone kryteria, dobór jednostek statystycznych mających być przedmiotem badań. Dobór celowy próby pożądany jest np. w każdym przypadku badania skuteczności określonych oddziaływań kierowniczych i decyzyjnych.

8 Oznaczają prowadzenie pogłębionych badań terenowych na niewielkiej liczbie osób. Każdy przypadek jest opisywany niemal odrębnie, zaś badacz stara się zrozumieć przyczyny zaobserwowanych różnic i podobieństw.

9 Testy statystyczne służą do oceny, czy zależności zaobserwowane $\mathrm{w}$ próbie są efektem ogólniejszej prawidłowości panującej w całej populacji czy tylko przypadkowym rezultatem. Wynikiem testu statystycznego jest tzw. prawdopodobieństwo testowe $(p)$, którego niskie wartości świadczą o istotności statystycznej rozważanej zależności. Przyjmuje się przy tym najczęściej następujące reguły:

- gdy $p \geq 0,05$ mówimy o braku podstaw do odrzucenia hipotezy zerowej, co oznacza, że testowana różnica, zależność, efekt nie jest znamienny statystycznie,

- gdy $p<0,05$ mówimy o statystycznie istotnej zależności (oznaczamy ten fakt za pomocą *),

$-p<0,01$ to wysoce istotna zależność (**),

$-p<0,001$ to bardzo wysoko istotna statystycznie zależność (***).

Niektórzy autorzy rekomendują przyjęcie bardziej liberalnego kryterium uznawania danego wyniku za istotny statystycznie, poprzez zastąpienie warunku $p<0,05$ warunkiem: $p<0,10$. Podejście takie wydaje się uzasadnione $\mathrm{w}$ przypadku niewielkiej liczności próby, gdy uzyskanie rezultatu istotnego statystycznie jest relatywnie mniej prawdopodobne (więcej na temat idei testowania hipotez statystycznych: A. SOKOŁOWSKI 2010, P. FRANCUZ i R. MACKIEWICZ 2007)

10 Test niezależności chi-kwadrat jest najpopularniejszym testem statystycznym służącym do badania zależności między dwiema cechami zmierzonymi na skali nominalnej. W teście tym stawiana jest hipoteza zerowa, że wystąpienie wariantu jednej cechy nie zależy od wariantu przyjmowanego dla drugiej cechy (cechy są niezależne). W hipotezie alternatywnej zakładane jest, iż cechy są ze sobą powiązane. Niskie wartości prawdopodobieństwa testowego $p$ pozwalają hipotezę zerową odrzucić i wnioskować o istnieniu zależności w całej populacji pomiędzy dwiema rozważanymi cechami. Szczegółowe procedury oblicze- niowe można znaleźć $\mathrm{w}$ wielu pozycjach $\mathrm{z}$ zakresu statystyki (por. ACZEL 2000, STANISZ 2001).

${ }^{11}$ Stosowano benchmarking: konkurencyjny (78\%), produktowy $(63 \%)$, wyników $(63 \%)$, funkcjonalny $(56 \%)$, procesowy (48\%), marketingowy (41\%), wewnętrzny (37\%), proceduralny $(22 \%)$, organizacyjny $(22 \%)$, strategiczny $(15 \%)$, projektu $(11 \%)$, ogólny (7\%), relacyjny (4\%).

12 Kwestionariusz ankiety zawierał pytanie dotyczące metod i koncepcji zarządzania wykorzystywanych przez pracowników i wśród odpowiedzi pojawiły się: outsourcing $56 \%$, zarządzanie jakością $41 \%$, zarządzanie wiedzą 30\%, zarządzanie strategiczne $26 \%$, zarządzanie partycypacyjne i lean management $11 \%$, timebased management $4 \%$. Analiza pozostałych pytań w ankiecie odnoszących się do źródeł działań innowacyjnych wskazała dodatkowo: analizę konkurencji i kontakty w ramach Star Alliance.

${ }^{13}$ Działalność badawczo-rozwojowa stanowi jeden z fundamentów sukcesu przedsiębiorstwa, a szukając benchmark-partnerów do porównań w działalności badawczo-rozwojowej uwagę powinno się skupić głównie na przedsiębiorstwach, działających $\mathrm{w}$ tym samym sektorze lub przedsiębiorstwach, które są kooperantami lub mogłyby być potencjalnymi kooperantami. Ciekawostkę może stanowić związane $\mathrm{z}$ tym pojęcie: benchgrafting - który jest przedostatnim etapem zastosowania benchmarkingu $\mathrm{w}$ działalności badawczo-rozwojowej przedsiębiorstwa, a służy prezentacji istotnej roli zastosowania radykalnych zmian wskutek wykorzystania benchmarkingu.

${ }^{14}$ Na przykład British Airways porównywały, ile czasu potrzebują różne linie lotnicze na rozładunek i ponowny załadunek Boeinga 747. Potrzebna była informacja, że japońskiej linii zajmuje to $40 \mathrm{~min}$, aby skłonić załogi BA do poprawienia własnego wyniku, wynoszącego 3 godziny (WRIGHT, RACE 2004, HOLLINS, SHINKINS 2009). Innym, często porównywanym aspektem, zwłaszcza wśród LCC jest tzw. godzina blokowa.

${ }_{15}$ Analiza dotyczy tylko tych osób, które wcześniej zadeklarowały stosowanie tego rodzaju benchmarkingu.

16 Uzyskiwane rozwiązania wydają się niekiedy proste, ale proces ich uzyskania może być skomplikowany i kosztowny.

${ }^{17}$ Dzięki benchmarkingowi wiele przedsiębiorstw osiągnęło znaczny wzrost innowacyjności (BOXWEL JR 1994, PAVITT 2005, TIDD, BESSANT, PAVITT 2005).

\section{BIBLIOGRAFIA}

ACZEL A.D., 2000, Statystyka w zarzadzaniu, PWN, Warszawa, 735 s. BANK J., 1997, Zarządzanie przez jakość, Wyd. Gebethner \& Ska, Warszawa, $236 \mathrm{~s}$.

BEDNARCZYK M., NAJDA-JANOSZKA M., 2014, Innowacje w turystyce. Regionalna przestrzeń wspótpracy w makroregionie potudniowym Polski, Wyd. CeDeWu, Warszawa, $243 \mathrm{~s}$.

Bogan CH.E., CALlaHAN D., 2001, Benchmarking in Rapid Time, „Industrial Management”, 43, 2, s. 28-33.

BOGAN CH.E., ENGLISH M.J., 2006, Benchmarking jako klucz do najlepszych praktyk, Wyd. Helion, Gliwice, $416 \mathrm{~s}$.

BOXWELL R.J. Jr, 1994, Benchmarking for Competitive Advantage, McGraw-Hill, New York.

BRACKENBURY M., 2004, Has innovation become a routine practice the enables companies to stay ahead of competition in the travel industry?, Paris, OECD Publishing, s. 1-8, http:// www.oecd. org/industry/tourism/34267968.pdf; 17.02.2017.

BRATNICKI M., STRUŻYNA J. (red.), 2001, Przedsiębiorczość $i$ kapitał intelektualny, Wyd. Akademii Ekonomicznej w Katowicach, Katowice, $205 \mathrm{~s}$.

BRILMAN J., 2002, Nowoczesne koncepcje i metody zarzadzania, PWE, Warszawa, $262 \mathrm{~s}$. 
CZEKAJ J., 1995, Benchmarking - metoda racjonalizacji organizacji, „Ekonomika i Organizacja Przedsiębiorstwa", 9, s. 5-7.

CZYŻ-GWIAZDA E., 2006, Rozwój controllingu procesów w matych $i$ średnich przedsiębiorstwach $z$ wykorzystaniem benchmarkingu, Prace Naukowe AE we Wrocławiu, 1101, s. 23-33.

FRANCUZ P., MACKIEWICZ R., 2007, Liczby nie wiedza skąd pochodza. Przewodnik po metodologii i statystyce, Wyd. KUL, Lublin, $654 \mathrm{~s}$.

GABRUSEWICZ G., KAMELA-SOWIŃSKA A., POETSCHKE H., 1998, Rachunkowość zarzadcza, PWE, Warszawa, $267 \mathrm{~s}$.

GADOMSKA-LILA K., 2011, Budowanie kultury innowacyjności w świetle badań empirycznych, „Współczesne Zarządzanie”, 1, s. 124-133.

GARVIN D.A., 1993, Building a learning organization, „Harvard Business Review", 71, 4, s. 78-91.

GIERCZAK B., 2014, Ocena wykorzystania źródet wiedzy w procesie benchmarkingu przez pracowników PLL LOT a poprawa jakości ustug turystycznych, [w:] Turystyka wobec zmian wspótczesnego świata. Zmiany, bariery, innowacje, G. Gołembski, A. Niezgoda (red.), Wyd. UE w Poznaniu, Poznań, s. 110-126.

GIERCZAK-KORZENIOWSKA B., 2016, Motywy $i$ cele zastosowania benchmarkingu w transporcie lotniczym na przykładzie Polskich Linii Lotniczych LOT S.A, „Studia Oeconomica Posnaniensia", 4, 7, s. 77-90, doi: 10.18559/SOEP.2016.7.4.

GRUDZEWSKI W.M., HAJDUK I.K., 2000, Przedsiębiorstwo przysztości, Difin, Warszawa, $332 \mathrm{~s}$

HAFFER M., 1997, Proces benchmarkingu jako metoda doskonalenia zarzadzania przedsiębiorstwem, Prace Naukowe AE Katowice, Katowice, s. 83-93.

HJALAGER A.M., 2010, A review of innovation research in tourism, „Tourism Management", 31, s. 1-12, doi: https://doi.org/ 10.1016/j.tourman.2009.08.012.

HolLINS B., SHINKINS S., 2009, Zarządzanie ustugami - projektowanie $i$ wdrażanie, PWE, Warszawa, $285 \mathrm{~s}$.

JANUSZEWSKA M., NAWROCKA E., 2015, Innowacyjność przedsiębiorstw turystycznych jako czynnik rozwoju regionu turystycznego, Prace Naukowe Uniwersytetu Ekonomicznego we Wrocławiu, 393, s. 111-119, doi: https://doi.org/10.15611/ pn.2015.393.11.

KAMANDE A.G., 1997, Benchmarking of Performance Measure Used in UK Engine Plants. Msc Thesis, Cranfield University, Cranfield, $26 \mathrm{~s}$.

KARLÖF B., ÖSTBLOM S., 1995, Benchmarking - równaj do najlepszych, Wyd. „Zarządzanie i Finanse - Józef Śnieciński”, Warszawa, $246 \mathrm{~s}$.

KOSIŃSKI M., 2004, Benchmarking, czyli porównywanie się z najlepszymi, [w:] Jak budować przewage konkurencyjna firmy?, K. Lisiecka (red.), RWTÜV Polska, Katowice, s. 69-74.

KOWALCZYK L., 2003, Benchmarking w zarządzaniu ustugami publicznymi, Prace Naukowe AE we Wrocławiu, „Zarządzanie i Marketing, 23, 964, s. 112-122.

KOSTERA M., 2003, Antropologia organizacji. Metodologia badań terenowych, PWN, Warszawa, $222 \mathrm{~s}$.

LISIECKA K., 2004, Jak budować przewage konkurencyjna firmy, RW TÜV Polska, Katowice, $99 \mathrm{~s}$.
MARCISZEWSKA B., 2014, Rola innowacyjności w procesie obstugi turysty, [w:] Turystyka wobec zmian wspótczesnego świata - zmiany, bariery, innowacje, G. Gołembski, A. Niezgoda (red.), Wyd. UE w Poznaniu, Poznań, s. 241-251.

MicZYŃSKA-KOWALSKA M., 2005, Wykorzystanie nowoczesnych koncepcji zarzadzania w działalności innowacyjnej przedsiębiorstwa, Prace Naukowe AE we Wrocławiu, 1086, s. 183-191.

NIEDZIELSKI P., RYCHLIK K., MARKIEWICZ J., 2008, Innowacyjne przedsiębiorstwo sektora ustug - nowe ścieżki rozwoju, IV Konferencja Naukowa z cyklu „Wiedza i innowacje. Fundusze unijne i przedsiębiorstwa w rozwoju nauki i gospodarki", Kraków 2008.

Oslo Manual. The Measurement of Scientific and Technological Activities. Proposed Guidelines for Collecting an Interpreting Technological Innovation Data, 2005, ODCE-EC-Eurostat.

PAVITT K., 2005, Innovation processes, [w:] J. Fagerberg, D.C. Mowery, R.R. Nelson (eds.), The Oxford Handbook of Innovation, Oxford University, Oxford, s. 86-114.

PORTER M., Ketels CH., Delgado M., 2007, The Microeconomic Foundations of Prosperity: Findings from the Business Competitiveness Index, [w:] The Global Competitiveness Index 20072008, World Economic Forums, Geneve, s. 51-81.

RAPACZ A., JAREMEN D.E., 2015, ICT a innowacje marketingowe w przedsiębiorstwach turystycznych, „Logistyka”, 2, s. 1346-1354.

RYCHLEWSKI C., 1998, Wygrać moga mąrzy i leniwi, „Prawo i Gospodarka", 1, s. 2-4.

SCHUMPETER J., 1960, Teoria rozwoju gospodarczego, Warszawa, $104 \mathrm{~s}$.

SIMATUPANG T.M., SRIDHARAN R., 2003, A Benchmarking Scheme for Supply Chain Collaboration, „Benchmarking: An International Journal", 9, 6, s. 5-30, doi: https://doi.org/10.1108/ 14635770410520285

SOKOŁOWSKI A., 2010, Estymacja $i$ testowanie hipotez, [w:] Statistica $w$ badaniach naukowych $i$ nauczaniu statystyki, Wyd. Stat Soft Polska, Kraków, s. 25-60.

STACHOWICZ-STANUSCH A., 2001, Kultura marketingowa przedsiebiorstw, Wyd. Naukowe PWN, Warszawa, $121 \mathrm{~s}$.

STANISZ A., 2001, Przystęny kurs statystyki w oparciu o program Statistica na przykładach z medycyny, Wyd. StatSoft Polska, Kraków, 532 s.

STAWASZ E., 1999, Innowacje a mata firma, Wyd. Uniwersytetu Łódzkiego, Łódź, $270 \mathrm{~s}$.

SUSZYŃSKI C., 2003, Restrukturyzacja, konsolidacja, globalizacja przedsiębiorstw, PWE, Warszawa, $128 \mathrm{~s}$.

TIDD J., BESSANT J., PAVITT K., 2005, Managing Innovation: Integrating Technological, Market and Organizational Change, $3^{\text {rd }}$ Ed., John Wiley, Hoboken, NJ, 602 s.

WISZNIEWSKI W., 1999, Innowacyjność polskich przedsiębiorstw przemystowych, Wyd. Instytut Organizacji i Zarządzania w Przemyśle „Orgmasz”, Warszawa, $140 \mathrm{~s}$.

WAWRZYNIAK B., 1999, Odnawianie przedsiębiorstwa na spotkanie XXI wieku, Warszawa, s. $126 \mathrm{~s}$.

Wright J.N., RACE P., 2004, The Management of Service Operations, Thomson Learning, Pensylwania, $346 \mathrm{~s}$.
Artykuł wpłynął do redakcji:

21 października $2016 \mathrm{r}$.

Zaakceptowano do druku: 9 grudnia $2016 \mathrm{r}$. 